\title{
OUTSTANDING ISSUES OF MILITARY LOGISTICS IN UKRAINE
}

\author{
Yurii KORNIICHUK \\ korniy.yg@gmail.com \\ Oleksandr SHKATULA \\ shkatula_a_p@ukr.net \\ Vladislav SMAGA \\ vladsm13@gmail.com \\ Korolov Zhytomyr Military Institute, \\ Ukraine
}

\begin{abstract}
The article presents an analysis of the definition of military logistics and historical and developmental analysis of military logistics in Ukraine. The current state and problems of military logistics in Ukraine are revealed. The approaches to application of Blockchain technology to military logistics are given. The article highlights the projected development of military logistics.

Streszczenie: Artykut zawiera analizę koncepcji treści logistyki wojskowej, analizy historycznej i ewolucyjnej logistyki wojskowej na Ukrainie. Aktualny stan i problemy logistyki wojskowej na Ukrainie zostały ujawnione. Podano podejścia do stosowania blokady w logistyce wojskowej. Artykut dotyczy prognozy dalszego rozwoju logistyki wojskowej.
\end{abstract}

Keywords: military logistics, logistics, logistics chains, information systems, information technologies, blockchain.

Slowa kluczowe: logistyka wojskowa, logistyka, tańcuchy logistyczne, systemy informacyjne, technologie informacyjne, blockchain.

\section{INTRODUCTION}

Historically, the ways of armed forces development have shown the inevitable dependence of the troops on supplies, therefore, in the modern world, logistics plays an important role, not only for small and large businesses, but also in military affairs. New technologies make it possible to implement practical and high-performance solutions that used to be impossible. That is why logistics must keep pace with scientific progress. The armed forces of developed countries pay great attention to logistics and are constantly working to improve the existing material and information systems and the creation of new ones, which must be strategically agreed, well-planned, and have a high level of control at all stages, with the fastest response to the critical issues.

The purpose of the article is to determine the problems of logistics and to bring proposals for their solution in the Armed Forces of Ukraine.

\section{RESEARCH RESULTS}

The modern system of logistics in the Armed Forces is not exclusively military, but military and economic, because under the market conditions not only large enterprises, but also small and 
medium-sized ones are involved for the logistical support of troops, and all of them operate according to the principles and laws of economic logistics. In general there are two fundamentally different interpretations of the notion of logistics - military logistics, which is interpreted as a direction of military science, associated with the movement and supply of armed forces, and mathematical logistics - the direction of using the mathematical apparatus to prove deductive allegations. Historically, a similarity between troop management and material resources management has been noticed.

For the first time, the possibility of using the provisions of military logistics in the economy was indicated by the US expert in the field of system analysis O. Morgenstern. The modern general meaning of the concept of "logistics" is based on a new thinking and combines new principles and approaches to the organization and management of various aspects of military and civilian economic activity at all its macro- and micro levels, their phases, and stages. Put simply, logistics is a scientific doctrine of planning, organizing and controlling all types of transfer and warehousing activities to ensure the passage of the entire chain from the procurement of raw materials to finished products, and from the moment of paying money to suppliers until the moment of receiving money from the consumer.

The meaningful content of the term military logistics is quite diverse and depends on the perspectives and ideas of scientists and experts, highlighting logistics issues in their monographs, scientific papers, and articles in some or other way [1-6].

Researchers in the field of military logistics have proved that, according to modern tasks, it is possible to distinguish such two types of logistics functions as operational and coordinating. Moreover, the first of them is connected with the direct control of the movements of material flows in the area of logistic build-up, distribution and transportation from warehouses and bases to consumers.

As for the function of coordinating military-economic logistics, it mostly has analytical nature, that is, can be defined as an analysis of the location of warehouses and depots of various types of provisioning (fuel and lubricants, subsistence and material support, etc.), the definition of the capabilities of specified routes and technical characteristics of vehicles, provisioning in the course of conducting warfare and carrying out activities related to the collection and processing of information.

The decisions on the organization of aimed actions of logistics services are taken following the analytics results. Military and economic logistics in the management process carries out an administration role. Its main functions include:

- controlling function - control within the whole logistics chain,

- organizational function - logistics planning, 
- management function - management of material and technical logistics services, as well as transport and information support of military units in peace and war time,

- $\quad$ strategic function - definition of strategy and technology of physical movement, transportation forecasting,

- accounting function - reporting on the availability, quality and status of material and technical means, as well as the legality of their expenditures.

The development of military logistics involves finding the most optimal, fastest and most qualitative ways of delivering supplies.

Until quite recently, military logistics in Ukraine has hardly developed, so the destabilization of the situation in the east of the country, which has caused full-scale military operations, has showed inefficiency of the Ukrainian Armed Forces and the defense complex in providing high-quality military operations. It was very difficult at the time to provide the necessary ammunition, supplies, weapons and equipment in sufficient scale. In addition, the Armed Forces were constantly in need of high-tech devices and software. The procurement was carried out with the help of volunteers. The lack of necessary knowledge of logistics has led to a logistical catastrophe in the field. Such a problem had to be dealt with expeditiously. Under those challenging circumstances the development of the Ukrainian logistics system began. Its primary role was to establish timely and qualitative technical equipment, communication, logistical resources and to create the functional infrastructure, which would ensure the success of tactical and strategic operations.

Such projects and reforms testify to the origin and formation of military economic logistics in Ukraine. Among them, we can identify: the Institutional Reform of Procurement Project; the Electronic Purchases Reform Project; the Automation of Accounting and Logistics in the Field of Supply of the Armed Forces of Ukraine Pilot Project.

The Institutional Procurement Reform Project. The reasons for the reform were as follows: poorly timed and provided provisioning of the Armed Forces of Ukraine with material, technical and subsistence support; the dispersal of functions for provisioning logistical and subsistence resources between various structural divisions of the Ministry of Defense and the General Staff of the Armed Forces of Ukraine. The overall aim of this reform is to provide efficient and transparent processes for quality logistical and subsistence supply in accordance with the arising needs. The stages of the implementation process of this project include:

1) Stage I - the reorganization of the department of public procurement and the supply of material resources to the procurement department;

2) Stage II - the creation of the Center for the organization of material support to the Armed Forces of Ukraine. The functions of this center will include: the development of new standards and 
norms of material and subsistence support and the implementation of logistics (automated logistics system, role definition, shift management, and creation of the specific-purpose operational model of logistics);

3) Stage III - the establishment of the Procurement Agency for housing support to the military personnel of the Armed Forces of Ukraine.

The Electronic Procurement Reform Project. The reforms are aimed at the adjustment and creation of the platform for the electronic auction, electronic document flow and the Department of Purchasing website. Their purpose is the creation of an open, transparent system of purchases in the Ministry of Defense of Ukraine.

The Automation of Accounting and Logistics in the Field of Supply of the Armed Forces of Ukraine Project. The strategic purpose of the project is the definition of the possibility of reduction of an indicator "admissible surplus"; creation of a quick delivery system of material support; reduction of "a human factor" in the process of accounting material support. Other purposes of the project are as follows: the reduction of logistic lag interval (from 5-20 days up to 2-10 days) due to expeditious exchange of information about supplies and the possibility of their movement; assurance of obtaining full and reliable information about supplies quarterly.

However, despite the reforms, the military logistics in Ukraine still lags behind the civil one. The War has brought out the problems of the Armed Forces of Ukraine, namely in the field of logistics, when the existing state of material support in military structures and the transport systems were not capable to address the challenges promptly and effectively. But, at present, the logistics is in good progress. According to the program of Ukrainian-American military exercises the "Fearless Guardian - 2015", Ukrainian armed forces exchanged the experience with other military forces. The international relations in the area of military logistics are being improved. Ukrainian patriots stimulate the integration efforts and resources of business sector and the Armed Forces of Ukraine. As a result of appropriate steps, there is a noticeable improvement of provisioning the Ukrainian army and its support concerning military logistics by other countries.

This suggests that the military and economic logistics in Ukraine is in rapid evolution.

As it has been noted above, the military logistics in Ukraine is advancing at a great rate. But progress is more directed to the areas supplies, but not information. It complicates performance of the registration and controlling functions.

The question at issue is that currently there is no single base of information storage. Instead of this, there is a great number of separate registers. The fact that each link of logistic chain uses the separate, decentralized databases makes the process of delivery control much more complicated. And it leads to multiple problems. 
One of them is the precondition of the emergence of corruption and inadequate performance of the appropriate responsibilities by functionaries. The anti-corruption activities waste a lot of time on processing and matching the required documents.

Another challenge is that, in most cases, commissioned officers are not able to find out at what stage the supply of the means necessary to their units is. This complicates the planning further military activities and increases the uncertainty factor.

Another problem is the slow response to the needs of units. Thus, the delivery time can exceed the waiting time by two or sometimes even three times, that greatly reduces the relevance of this delivery.

Under such circumstances, it is not easy to organize a clear cooperation with civilian economic structures, since it complicates the creation and submission of orders for business sector in general.

In addition, the Armed Forces of Ukraine do not have a common structure of military logistics. The provision and supply of resources, weapons, equipment, property and food are divided among several separate structures, which should constantly cooperate with each other for the effective performance of tasks. Due to the large number of documents, that must be processed by these structures for the organization of cooperation, a large amount of time is spent and, simultaneously, inconveniences, that could be avoided, emerge.

So, analyzing these problems, one can come to the conclusion that it is necessary to develop not only material but also informational aspects of the development of military logistics. Solving the problems of controlling and accounting of logistic chains can significantly optimize and facilitate the process of supplying troops, as well as increase its quality.

In order to solve many logistical problems, related to the information component of the system, world companies use one of the most discussed modern technologies, namely Blockchain. First of all, it should be noted that Blockchain is a publicly available and unchangeable digital register, where information is stored in interconnected blocks. Thus, while creating a new block with information, the previous ones are also involved, that determines the high reliability of this technology.

The first time the Blockchain technology was described in 1991 by Stewart Haber and Scott Stornett. They wanted to introduce a system in which the contents of the documents could not be distorted or damaged. But, it was developed only in 2008 by a programmer or a group of programmers under the nickname Satoshi Nakamato. Some important technical problems, that previously prevented the technology from functioning, were solved and the billing system in the network "bitcoin"- was introduced. Later, some other systems emerged, for example, "etherium". 
Today, blockchain is widely used by civilian logistics companies. An advanced company that develops this technology is the American IT company IBM (International Business Machines Corporation). The Vol-Mart chain of stores, which is successfully using this technology for supplying goods in the US and China was one of the first to test the benefits of blockchain. The company argues that this way the efficiency of product management improves and reliability increases. They consider paper document circulation long outdated. Other examples include such companies as a diamond trading company EverLager; Midasium, which deals with property market contracts; the Maersk, which deals with the transportation of goods and others.

This technology is successfully used by Ukrainian companies as well. In this area, such projects as Rentberry, analogous to foreign Midasium, and a blockschain platform for the sale of real estate Ambisafe, are successfully functioning. In June 2017, the Cabinet of Ministers of Ukraine approved a draft on the creation of a blockchain land registry.

During the 2018 World Economic Forum in Davos, 14 countries were named to be leaders using blockchain technology. The United States, Canada, Germany, France, Ukraine and others are among them.

This technology is rapidly gaining popularity due to its numerical advantages over conventional paper documents and other electronic accounting systems. It provides high reliability and the ability to monitor deliveries in real time throughout the logistics chain, and significantly reduces the time spent on processing documents, and, as a result, increases efficiency. It is possible to create both open and closed systems.

The experience of using blockchain technology in civilian logistics entails the implementing this technology in military logistics. In the future, it can solve a number of issues concerning the information component of science discussed above.

Today, the US Army is actively exploring the use of blockchain technology in this area. The US Air Force Command is introducing this technology into aircraft component supply systems. This will reduce the cost of their maintenance. But nowadays the blockchain technology is used only for small supplies.

\section{CONCLUSIONS}

In our opinion, the creation of a single electronic system, which will consist of several private information chains, will give each officer the opportunity to monitor the execution of their orders and, at the same time, control them in real time, which will provide assurance of the direct planning of the unit's actions. In military affairs, everything must be precise. It is also possible to control the distribution of various maintenance types of supplies within a large military unit. It will also increase 
the response to the needs of troops that will positively affect the armed forces. This technology can complement existing control systems in the troops.

The Scientific Center of the Armed Forces of Ukraine in Kyiv is already reviewing certain decisions to establish a new supply chain control system based on the information chain. So far, they remain imperfect. Several technical issues need to be addressed. To create an electronic accounting register requires a great computer systems performance. Another problem is the lack of well-trained specialists in this field.

Consequently, military logistics, as a science, develops contemporary with technological progress in the world. Although, currently, there are certain problematic issues in this area and suggestions for their solutions. Perhaps in the near future we will see a completely new logistics system, which is based on electronic register accounting.

\section{REFERENCES:}

[1] BURDIAK, O. M. (2018). Kliyentooriyentovana logistyka v internet-torhivli [Customer-oriented logistics in Internet commerce. Electronic resource: http://nbuv.gov.ua/UJRN/Vchtei_2018_1-2_34. Bulletin of the Chernivtsi Trade and Economic Institute. Economic Sciences, 1-2, 222-228.

[2] VOLONTYR, L. O. (2018). Informatsiina logistyka biznes-struktur malyh pidpryyemstv. Information logistics of small enterprises business structures. Electronic resource: http://nbuv.gov.ua/UJRN/bses_2018_34_44. Black Sea Economic Studies, 34, 198-202.

[3] ROHANOV, C. (2018). Blockhainyavlyayetsyaproryvomiosnovnoydlyatsepeypostavokbuduschego. Blockchain is a breakthrough and key to future supply chains. Logistics: problems and solutions, 3(76), 25-27.

[4] SKITSKO V. I. (2016). Logistyka $v$ industrii 4.0. Logistics in the industry 4.0. Electronic resource: http://nbuv.gov.ua/UJRN/ecde_2016_4_7. Economy and the state, 4, 8-33.

[5] LOGISTICS: PROBLEMS AND SOLUTIONS. (2018). Smart-logistika na voyennoy sluzhbe: obzor mirovyh voiskovyh transportnyh sryedstv. Smart logistics in the military service: an overview of the world's military vehicles. Logistics: problems and solutions, 4(77), 24-35.

[6] SuMETS, A. M. (2018). Smart-produkty dlya logistiki. Smart products for logistics. Logistics: problems and solutions, 3(76),42-51. 